Article

\title{
Steady-State Methodology for Activated Sludge Model 1 (ASM1) State Variable Calculation in MBR
}

\author{
Ameni Lahdhiri ${ }^{1}$, Geoffroy Lesage ${ }^{2} \mathbb{D}$, Ahmed Hannachi ${ }^{1} \mathbb{D}$ and Marc Heran ${ }^{2, *}$ \\ 1 Process and Chemical Engineering Department, Gabes National Engineering School, Gabes University, \\ Gabes 6029, Tunisia; amenilah@gmail.com (A.L.); ahmed.hannachi@enig.rnu.tn (A.H.) \\ 2 Institut Européen des Membranes (IEM), Univ Montpellier, 34090 Montpellier, France; \\ geoffroy.lesage@umontpellier.fr \\ * Correspondence: marc.heran@umontpellier.fr
}

Received: 9 October 2020; Accepted: 11 November 2020; Published: 17 November 2020

check for updates

\begin{abstract}
The complexity of Activated Sludge Model No. 1 (ASM1) is one of the main obstacles slowing its widespread use, particularly among wastewater treatment plant (WWTP) professionals. In this paper, a simplification procedure based on steady-state mass balances is proposed for the conventional activated sludge process (ASP) configuration, consisting of an aerated bioreactor and a perfect settler (without particular compounds in the outlet). The results do, in fact, show perfect suitability to a membrane bioreactor process (MBR). Both organic carbon and nitrogen removal were investigated. The proposed approach was applied to ASM1, and simple analytical expressions of the state variables were obtained. These analytical expressions were then validated by comparison to simulations given by the original ASM1 (implemented in GPS-X software). A strong match (less than $4 \%$ of error overall) was obtained between both results in the steady-state; consequently, these analytical expressions may be useful as tools for quickly estimating the main state variables, feeding the filtration models, or identifying the interaction between operating parameters. Moreover, this enables a sensitivity analysis, covering relevant factors such as kinetics or operating parameters. For instance, the sludge retention time (SRT) effect is lower on $\mathrm{X}_{\mathrm{BH}}$ and $\mathrm{X}_{\mathrm{S}}$ at high SRT (>20 days), while it is more pronounced on $X_{P}$ and $X_{I}$ as their variations with SRT are linear.
\end{abstract}

Keywords: biological wastewater treatment; activated sludge model; steady-state modeling; sensitivity analysis

\section{Introduction}

The importance of modeling activated sludge processes (ASPs) for domestic wastewater treatment has increased in recent decades, particularly with the advent of the widely accepted activated sludge models (ASMs) [1]. ASMs have shown promising predictive results, but at the expense of complex process models [2]. Even with the use of the continuously stirred tank reactor (CSTR) assumption, a highly nonlinear system of ordinary differential equations is obtained [3]. This complexity is one of the main obstacles holding up the widespread us of ASMs, particularly among WWTP professionals asking for model simplification [2,3]. Since a full model is not always necessary for all users and all applications, various application-motivated ASM simplification studies have been conducted, all concerning only Activated Sludge Model No. 1 (ASM1) [4]. Different strategies for ASM1 simplification have been adopted, such as model dimension reduction [5-7], linearization of reaction rates [8,9], or whole mass balance equations [10].

Furthermore, to efficiently control the process, a sensitivity analysis is required to identify the most influential parameters. The most common method consists of making a variation of one parameter at a time in a specific range, generally at $+10 \%$ and $-10 \%$ of the parameter's usual value, and then 
quantifying the influence of this change for all state variables. However, this method results in a high number of simulations to perform, with, most often, long calculation times [11]. Thus, the International Water Association has launched a task group on membrane bioreactor (MBR) modeling and control, which works on multiobjective performance assessment, to enhance good MBR modeling [12].

In this paper, another simplification procedure based on steady-state mass balances is proposed for ASM1. It provides the analytical expressions of the main state variables once stabilized operation is reached. The objective is to explain, step by step, the methodology used to obtain analytical expressions for a very common ASP configuration used in WWTP (aerated CSTR) in order to provide a rapid estimation of the sludge composition and active biomass concentrations. The impact of each kinetic, stoichiometric, or operating parameter on a state variable is directly given, without a time-consuming sensitivity analysis. These expressions can be used mainly by domestic wastewater professionals as practical but still quite accurate tools for new plant design or for existing WWTP control. In addition, they may be adopted to simply feed the fouling model of MBR units.

\section{Materials and Methods}

\subsection{Biological Pathway and Variables}

In this study, ASM1 was adopted. All relationships between state variables are described in the Petersen matrix [4]. This matrix enables the writing of each state variable mass balance depending on the plant configuration. For this research, a basic but very common ASP configuration was implemented. It consists of a single aerated continuously stirred bioreactor, followed by a settling tank with a sludge recycle line from the settler to the bioreactor (Figure 1). Total retention of particulate compounds was assumed in the settler. Hence, the system could be assimilated to an MBR as perfect solid/soluble separation is ensured. Only aerobic processes associated with organic carbon removal and nitrification takes place within the bioreactor. Despite the importance of hydrodynamic phenomena in ASP modeling, hydrodynamics effects were neglected; the bioreactor and the settler were treated as CSTRs [2] (Figure 1).

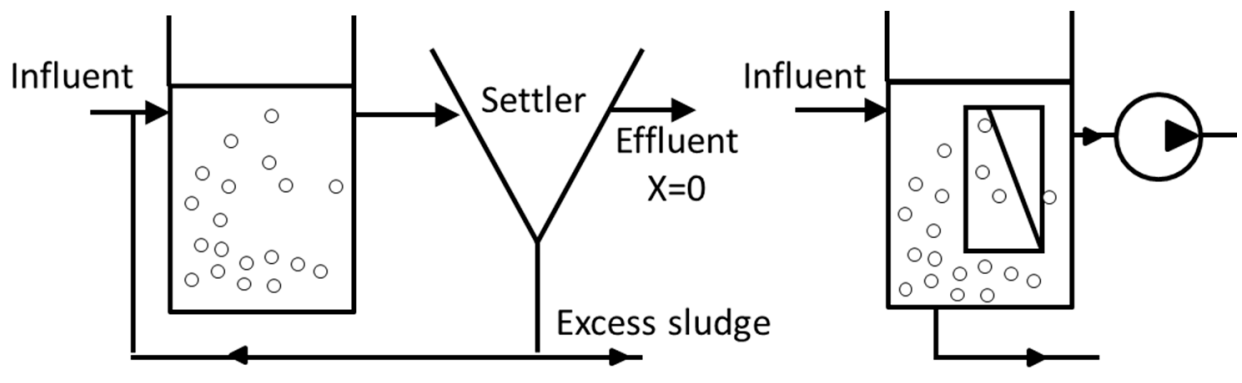

Figure 1. Adopted activated sludge process (ASP) configurations: Conventional Activated Sludge (CAS) and membrane bioreactor process (MBR).

As was common in previous studies, it was assumed that there were (i) no limitations in the dissolved oxygen $\left(\mathrm{S}_{\mathrm{O}}\right)$, ammonia (required for biomass growth), or alkalinity, and (ii) no denitrification. These assumptions lead to obtaining biomass concentrations $\left(\mathrm{X}_{\mathrm{BH}}, \mathrm{X}_{\mathrm{BA}}\right)$ in relation to their respective substrate (COD and ammonium) instead of reducing biomass growth due to alkalinity or nitrogen. Subsequently, the settler presented complete retention of the suspended solids and, of course, active biomass $\left(\mathrm{X}_{\mathrm{BA}}\right.$ and $\left.\mathrm{X}_{\mathrm{BH}}\right)$. As it was assumed that all particulate compounds were entirely retained, the equations developed are perfectly adapted to MBR. The Petersen matrix used is the one developed for ASM1. The following figure summarises the biological pathway (Figure 2).

In addition, it was assumed that all particulate compounds were entirely retained by the settler, meaning that these compounds were totally recycled to the bioreactor. For this reason, mass balances of state variables were applied only for the bioreactor. The set of differential equations comes from 
Henze et al. [4]. Soluble compounds were linked to hydraulic retention time (HRT), whereas particular compounds were linked to sludge retention time (SRT).

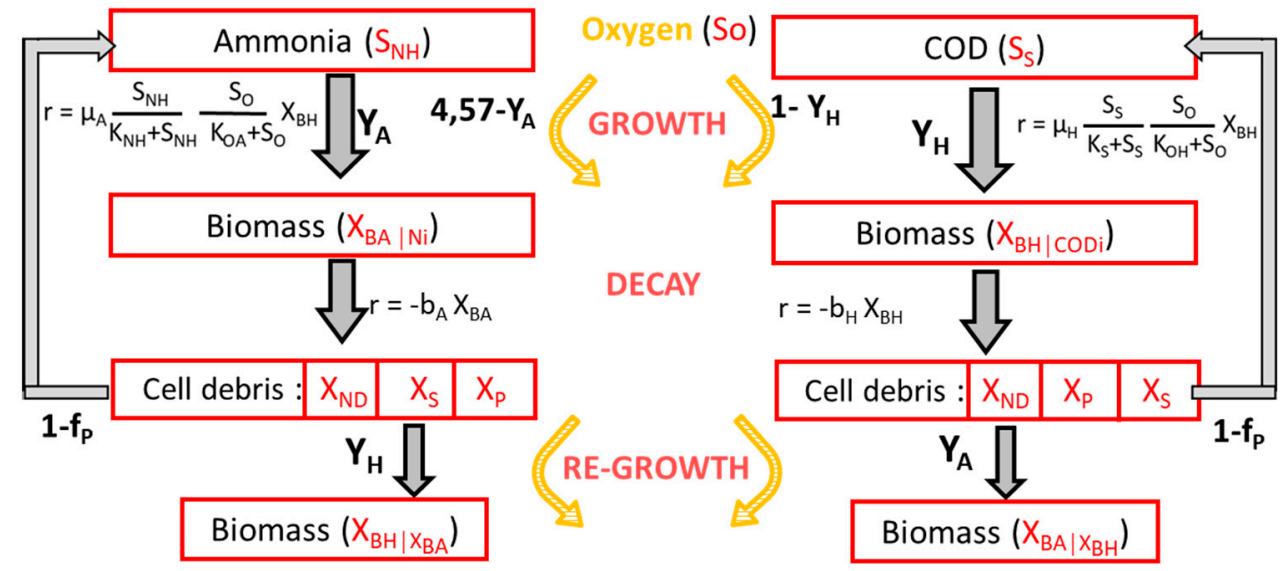

Figure 2. Process, stoichiometric $\left(\mathrm{Y}_{\mathrm{H}}, \mathrm{Y}_{\mathrm{A}}, \mathrm{f}_{\mathrm{p}}\right)$, and kinetic $\left(\mu_{\mathrm{H}}, \mathrm{b}_{\mathrm{H}}, \mathrm{K}_{\mathrm{S}}, \mathrm{K}_{\mathrm{OH}} ; \mu_{\mathrm{A}}, \mathrm{b}_{\mathrm{A}}, \mathrm{K}_{\mathrm{NH}}, \mathrm{K}_{\mathrm{OA}}\right)$ parameters related to biomass activity under aerobic conditions (Activated Sludge Model No. 1 (ASM1)).

\subsection{Operating Parameters}

Based on ASM1, analytical expressions of state variables in the steady-state operation were developed. To validate the obtained expressions, simulations using full ASM1 were conducted by means of the GPS-X software developed by Hydromantis in order to generate realistic data. Simulation conditions are presented in Table 1, demonstrating how influent concentration varied in the soluble substrate $\left(\mathrm{S}_{\mathrm{S}, \mathrm{i}}\right.$ and $\left.\mathrm{S}_{\mathrm{NH}, \mathrm{i}}\right)$. The additional substrates were fixed to $\mathrm{X}_{\mathrm{Si}}=200 \mathrm{mgCOD} / \mathrm{L}, \mathrm{X}_{\mathrm{NDi}}=10 \mathrm{mgN} / \mathrm{L}$, and $\mathrm{S}_{\mathrm{NDi}}=5 \mathrm{mgN} / \mathrm{L}$.

Table 1. Simulation operating conditions for expression validation (HRT $=0.33$ day).

\begin{tabular}{cccccc}
\hline Condition & $\begin{array}{c}\mathbf{S}_{\mathbf{N H i}} \\
(\mathbf{m g N / L})\end{array}$ & $\begin{array}{c}\mathbf{S}_{\mathbf{S i}} \\
(\mathbf{m g C O D} / \mathbf{L})\end{array}$ & $\begin{array}{c}\text { OLR } \\
(\mathbf{g C O D} / \mathbf{L} / \text { day })\end{array}$ & COD/N (-) & SRT (day) \\
\hline $1-4$ & 20 & 200 & 1.2 & 11.43 & $60,40,20,10$ \\
$5-8$ & 45 & 500 & 2.1 & 11.67 & $60,40,20,10$ \\
$9-12$ & 45 & 200 & 1.2 & 6.67 & $60,40,20,10$ \\
$13-16$ & 70 & 800 & 3 & 11.76 & $60,40,20,10$ \\
$17-20$ & 70 & 500 & 2.1 & 8.24 & $60,40,20,10$ \\
$21-24$ & 70 & 200 & 1.2 & 4.71 & $60,40,20,10$ \\
\hline
\end{tabular}

After that, results given by the analytical expressions and simulations were compared. ASM1 default parameters at $20^{\circ} \mathrm{C}$, given in Table 2, were used.

Table 2. ASM1 default parameters under aerobic conditions at $20{ }^{\circ} \mathrm{C}$ [4].

\begin{tabular}{clccc}
\hline & \multicolumn{1}{c}{ Parameter } & Symbol & Unit & Value \\
\hline \multirow{2}{*}{$\begin{array}{c}\text { Stoichiometric } \\
\text { parameters }\end{array}$} & $\begin{array}{l}\text { Heterotrophic yield } \\
\text { Autotrophic yield } \\
\text { Fraction of biomass yielding } \\
\text { particulate products }\end{array}$ & $\mathrm{Y}_{\mathrm{H}}$ & gCOD/gCOD & 0.67 \\
& $\begin{array}{l}\text { Nitrogen content of the biomass } \\
\text { Nitrogen content of the inert } \\
\text { lysis products }\end{array}$ & $\mathrm{f}_{\mathrm{P}}$ & - & 0.24 \\
\hline & $\mathrm{i}_{\mathrm{XB}}$ & $\mathrm{gN} / \mathrm{gCOD}$ & 0.086 \\
\hline
\end{tabular}


Table 2. Cont

\begin{tabular}{|c|c|c|c|c|}
\hline & Parameter & Symbol & Unit & Value \\
\hline \multirow{7}{*}{ Kinetic parameters } & $\begin{array}{l}\text { Heterotrophic maximum specific } \\
\text { growth rate }\end{array}$ & $\mu_{\mathrm{H}}$ & 1/day & 6 \\
\hline & Heterotrophic decay rate & $b_{\mathrm{H}}$ & 1/day & 0.62 \\
\hline & $\begin{array}{l}\text { Autrotrophic maximum specific } \\
\text { growth rate }\end{array}$ & $\mu_{\mathrm{A}}$ & 1/day & 0.8 \\
\hline & Autrotrophic decay rate & $\mathrm{b}_{\mathrm{A}}$ & 1/day & 0.18 \\
\hline & $\begin{array}{l}\text { Half-saturation coefficient for } \\
\text { heterotrophic biomass }\end{array}$ & $\mathrm{K}_{\mathrm{S}}$ & $\mathrm{gCOD} / \mathrm{m}^{3}$ & 20 \\
\hline & Maximum specific hydrolysis rate & $\mathrm{k}_{\mathrm{h}}$ & $\mathrm{gCOD} / \mathrm{gCOD} /$ day & 3 \\
\hline & $\begin{array}{l}\text { Half-saturation coefficient for } \\
\text { hydrolysis of } X_{S}\end{array}$ & $\mathrm{~K}_{\mathrm{X}}$ & $\mathrm{gCOD} / \mathrm{gCOD}$ & 0.03 \\
\hline
\end{tabular}

\subsection{Methodology}

\subsubsection{Internal Loop Management}

According to the biological pathway (Figure 2), a fraction of heterotrophic biomass is generated from autotrophic cell lysis products. In the same way, a fraction of autotrophic biomass is generated from heterotrophic cell lysis products. To reduce the complexity of mass balances, it is crucial to evaluate the contribution of each population fraction growing on the other population residues to the total concentration-in other words, to estimate the two ratios $i_{X B H \mid X B A}$ and $i_{X B A \mid X B H}$ given by Equations (1) and (2):

$$
\begin{aligned}
& \mathrm{i}_{\mathrm{BH} \mid \mathrm{X}_{\mathrm{BA}}}= \frac{\mathrm{X}_{\mathrm{BH} \mid \mathrm{X}_{\mathrm{BA}}}}{\mathrm{X}_{\mathrm{BH} \mid \mathrm{COD}}+\mathrm{X}_{\mathrm{BH} \mid \mathrm{X}_{\mathrm{BA}}}} \\
& \mathrm{i}_{X_{\mathrm{BA} \mid \mathrm{X}_{\mathrm{BH}}}}=\frac{\mathrm{X}_{\mathrm{BA} \mid \mathrm{X}_{\mathrm{BH}}}}{\mathrm{X}_{\mathrm{BA} \mid \mathrm{N}_{\mathrm{i}}}+\mathrm{X}_{\mathrm{BA} \mid \mathrm{X}_{\mathrm{BH}}}}
\end{aligned}
$$

where $\mathrm{X}_{\mathrm{BH} \mid \mathrm{XBA}}$ is the amount of heterotrophic biomass growing on the particulate organic substrate $\left(\mathrm{X}_{\mathrm{S}}\right)$ generated during autotrophic biomass decay, and $\mathrm{X}_{\mathrm{BH} \mid \mathrm{CODi}}$ is the amount of heterotrophic biomass growing on the organic substrate present in the influent $\left(\mathrm{COD}_{\mathrm{i}}\right)$.

In order to calculate $\mathrm{X}_{\mathrm{BH} \mid \mathrm{XBA}}$, we had to isolate the heterotrophic biomass growing on the debris of the autotrophic biomass from the heterotrophic biomass growing on the organic substrate present in the influent. For this purpose, the same basic ASP system described above (Figure 1) was used with an influent consisting only of nitrogen compounds, i.e., no organic carbon substrate was present.

In steady-state conditions, mass balance on ammonium is given by

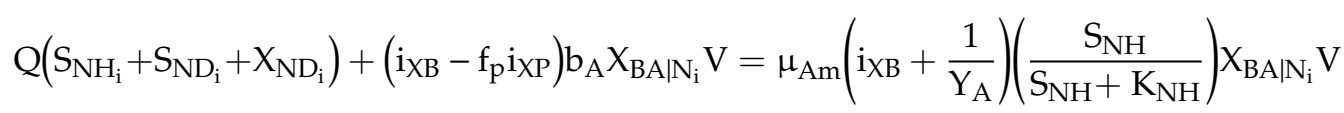

where $\mathrm{Q}$ is the influent flow rate (L/day), and $\mathrm{V}$ is the bioreactor volume $(\mathrm{L})$.

The term $\mathrm{i}_{\mathrm{XB}}-\mathrm{f}_{\mathrm{P}} \mathrm{i}_{\mathrm{XP}}$ represents the amount of particulate organic nitrogen $\left(\mathrm{X}_{\mathrm{ND}}\right)$ produced during active biomass decay. It should be mentioned that according to Equation (3), ammonium transformation from $X_{\mathrm{ND}}$ was total and not limited by hydrolysis and ammonification rates.

Mass balance on the autotrophic biomass is described as follows:

$$
\mu_{\mathrm{Am}} \frac{\mathrm{S}_{\mathrm{NH}}}{\mathrm{S}_{\mathrm{NH}}+\mathrm{K}_{\mathrm{NH}}} \mathrm{X}_{\mathrm{BA} \mid \mathrm{N}_{\mathrm{i}}} \mathrm{V}=\mathrm{Q}_{\mathrm{W}} \mathrm{X}_{\mathrm{BA} \mid \mathrm{N}_{\mathrm{i}}}+\mathrm{b}_{\mathrm{A}} \mathrm{X}_{\mathrm{BA} \mid \mathrm{N}_{\mathrm{i}}} \mathrm{V}
$$

where $\mathrm{Q}_{W}$ is the waste sludge flow rate (L/day).

Equation (4) means that the autotrophic biomass concentration is stabilized when the growth rate is compensated by the wastage and the decay rate. 
From Equation (4), the following can be produced:

$$
\mu_{\mathrm{Am}} \frac{\mathrm{S}_{\mathrm{NH}}}{\mathrm{S}_{\mathrm{NH}}+\mathrm{K}_{\mathrm{NH}}}=\mathrm{b}_{\mathrm{A}}+\frac{1}{\mathrm{SRT}}
$$

According to Equations (3) and (5), autotrophic biomass concentration can be expressed by Equation (6):

$$
X_{B A \mid N_{i}}=\frac{Y_{A}\left(S_{N_{i}}+S_{N D_{i}}+X_{N_{i}}\right) S R T / H R T}{\left(1+Y_{A} i_{X B}\right)\left(1+b_{A} S R T\right)-Y_{A} b_{A} S R T\left(i_{X B}-f_{p} i_{X P}\right)}
$$

Meanwhile, mass balance on the heterotrophic biomass is given by Equation (7):

$$
\mathrm{Y}_{\mathrm{H}}\left(1-\mathrm{f}_{\mathrm{P}}\right) \mathrm{b}_{\mathrm{A}} \mathrm{X}_{\mathrm{BA} \mid N_{\mathrm{i}}} \mathrm{V}=\mathrm{Q}_{\mathrm{W}} \mathrm{X}_{\mathrm{BH} \mid \mathrm{X}_{\mathrm{BA}}}+\mathrm{b}_{\mathrm{H}} \mathrm{X}_{\mathrm{BH} \mid \mathrm{X}_{\mathrm{BA}} \mathrm{V}} \mathrm{V}
$$

Consequently, heterotrophic biomass concentration growing on autotrophic biomass debris is determined as follows:

$$
X_{\mathrm{BH} \mid \mathrm{X}_{\mathrm{BA}}}=\frac{\mathrm{Y}_{\mathrm{H}}\left(1-\mathrm{f}_{\mathrm{P}}\right) \mathrm{b}_{\mathrm{A}} \mathrm{SRT}}{1+\mathrm{b}_{\mathrm{H}} \mathrm{SRT}} \mathrm{X}_{\mathrm{BA} \mid \mathrm{N}_{\mathrm{i}}}
$$

For the calculation of $\mathrm{X}_{\mathrm{BA} \mid \mathrm{XBH}}$, the same approach was used to isolate the autotrophic biomass growing on the debris of the heterotrophic biomass. This time, the influent consisted only of organic carbon substrate. However, it was assumed that there was enough ammonium in the bioreactor for biomass growth. Therefore, mass balance on the organic carbon substrate is shown in Equation (9):

$$
\mathrm{Q}\left(\mathrm{S}_{\mathrm{S}_{\mathrm{i}}}+\mathrm{X}_{\mathrm{S}_{\mathrm{i}}}\right)+\left(1-\mathrm{f}_{\mathrm{P}}\right) \mathrm{b}_{\mathrm{H}} \mathrm{X}_{\mathrm{BH} \mid \mathrm{COD}_{\mathrm{i}}} \mathrm{V}=\frac{1}{\mathrm{Y}_{\mathrm{H}}} \mu_{\mathrm{Hm}} \frac{\mathrm{S}_{\mathrm{S}}}{\mathrm{S}_{\mathrm{S}}+\mathrm{K}_{\mathrm{S}}} \mathrm{X}_{\mathrm{BH} \mid \mathrm{COD}_{\mathrm{i}}} \mathrm{V}
$$

Concerning the heterotrophic biomass, the mass balance in steady-state operation is depicted in Equation (10):

$$
\mu_{\mathrm{Hm}} \frac{\mathrm{S}_{\mathrm{S}}}{\mathrm{S}_{\mathrm{S}}+\mathrm{K}_{\mathrm{S}}} \mathrm{X}_{\mathrm{BH} \mid \mathrm{COD}_{\mathrm{i}}} \mathrm{V}=\mathrm{Q}_{\mathrm{W}} \mathrm{X}_{\mathrm{BH} \mid \mathrm{COD}_{\mathrm{i}}}+\mathrm{b}_{\mathrm{H}} \mathrm{X}_{\mathrm{BH} \mathrm{COD}_{\mathrm{i}}} \mathrm{V}
$$

This results in Equation (11):

$$
\mu_{\mathrm{Hm}} \frac{\mathrm{S}_{\mathrm{S}}}{\mathrm{S}_{\mathrm{S}}+\mathrm{K}_{\mathrm{S}}}=\mathrm{b}_{\mathrm{H}}+\frac{1}{\mathrm{SRT}}
$$

Based on Equations (9) and (11), the expression of heterotrophic biomass concentration was obtained:

$$
X_{\mathrm{BH} \mid \mathrm{COD}_{\mathrm{i}}}=\frac{\mathrm{Y}_{\mathrm{H}}\left(\mathrm{S}_{\mathrm{S}_{\mathrm{i}}}+\mathrm{X}_{\mathrm{S}_{\mathrm{i}}}\right) \text { SRT/HRT }}{1+\mathrm{b}_{\mathrm{H}} \mathrm{SRT}\left(1-\mathrm{Y}_{\mathrm{H}}\left(1-\mathrm{f}_{\mathrm{P}}\right)\right)}
$$

Mass balance on the autotrophic biomass is represented by Equation (13):

$$
\mathrm{Y}_{\mathrm{A}} \mathrm{i}_{\mathrm{XP}}\left(1-\mathrm{f}_{\mathrm{P}}\right) \mathrm{b}_{\mathrm{H}} \mathrm{X}_{\mathrm{BH} \mid \mathrm{COD}_{\mathrm{i}}} \mathrm{V}=\mathrm{Q}_{\mathrm{W}} \mathrm{X}_{\mathrm{BA} \mid \mathrm{X}_{\mathrm{BH}}}+\mathrm{b}_{\mathrm{A}} \mathrm{X}_{\mathrm{BA} \mid \mathrm{X}_{\mathrm{BH}}}
$$

where $i_{X P}\left(1-f_{P}\right) b_{H} X_{B H \mid C O D i}$ is the particulate organic nitrogen amount $\left(X_{N D}\right)$ released during biomass decay.

Thus, autotrophic biomass concentration growing on heterotrophic biomass debris is given by Equation (14):

$$
X_{B A \mid X_{B H}}=\frac{Y_{A} i_{X P}\left(1-f_{P}\right) b_{H}}{1+b_{A} S R T} X_{B H \mid C O D_{i}}
$$

At last, $\mathrm{i}_{\mathrm{XBH} \mid \mathrm{XBA}}$ and $\mathrm{i}_{\mathrm{XBA} \mid \mathrm{XBH}}$ can be calculated. Their expressions are functions of different operating conditions: total $\mathrm{COD}\left(\mathrm{COD}_{\mathrm{i}}\right)$ and nitrogenous compounds $\left(\mathrm{N}_{\mathrm{i}}\right)$ present in the influent, HRT, and SRT. Numerous calculations were conducted to estimate $i_{X B H \mid X B A}$ and $i_{X B A \mid X B H}$ for various $C O D_{i}$ and SRT values. We varied $C \mathrm{CD}_{\mathrm{i}}$ to cover a wide range of $\mathrm{COD} / \mathrm{N}$ ratios encountered in 
domestic wastewater treatment. It was found that SRT had a negative effect on $\mathrm{i}_{\mathrm{XBA} \mid \mathrm{XBH}}$, unlike $\mathrm{COD}_{\mathrm{i}}$. Exactly the opposite trend was noticed for $\mathrm{i}_{X \mathrm{XH} \mid \mathrm{XBA}}$, with a positive effect of SRT on $\mathrm{i}_{\mathrm{XBH} \mid \mathrm{XBA}}$ and a negative effect of $\mathrm{COD}_{\mathrm{i}}$ on $\mathrm{i}_{\mathrm{XBH} \mid \mathrm{XBA}}$. More importantly, for all simulations, $\mathrm{i}_{\mathrm{XBH} \mid \mathrm{XBA}}$ did not exceed $2 \%$, whereas $\mathrm{i}_{\text {ХВА|ХВН }}$ exceeded $5 \%$ in some cases, notably at values of SRT lower than 10 days. In light of these findings, the fraction of heterotrophic biomass $\mathrm{X}_{\mathrm{BH} \mid \mathrm{XBA}}$ growing on the particulate organic substrate $\left(X_{S}\right)$ generated by the decay of the autotrophic species was overlooked for the remainder of this study. This means that the autotrophic biomass does not interfere with heterotrophic biomass activity, reducing the interaction between both populations.

\subsubsection{Expressions of State Variable Concentrations in the Bioreactor}

For the reasons stated earlier, autotrophic lysis products were not accounted for in mass balances related to heterotrophic activity.

Mass balances on the soluble organic substrate $\left(\mathrm{S}_{\mathrm{S}}\right)$ and the heterotrophic biomass $\left(\mathrm{X}_{\mathrm{BH}}\right)$ gave Equations (15) and (16), similar to Equations (9) and (10), respectively:

$$
\begin{gathered}
\mathrm{Q}\left(\mathrm{S}_{\mathrm{S}_{\mathrm{i}}}+\mathrm{X}_{\mathrm{S}_{\mathrm{i}}}\right)+\left(1-\mathrm{f}_{\mathrm{P}}\right) \mathrm{b}_{\mathrm{H}} \mathrm{X}_{\mathrm{BH}} \mathrm{V}=\frac{1}{\mathrm{Y}_{\mathrm{H}}} \mu_{\mathrm{Hm}} \frac{\mathrm{S}_{\mathrm{S}}}{\mathrm{S}_{\mathrm{S}}+\mathrm{K}_{\mathrm{S}}} \mathrm{X}_{\mathrm{BH}} \mathrm{V} \\
\mu_{\mathrm{Hm}} \frac{\mathrm{S}_{\mathrm{S}}}{\mathrm{S}_{\mathrm{S}}+\mathrm{K}_{\mathrm{S}}} \mathrm{X}_{\mathrm{BH}} \mathrm{V}=\mathrm{Q}_{\mathrm{W}} \mathrm{X}_{\mathrm{BH}}+\mathrm{b}_{\mathrm{H}} \mathrm{X}_{\mathrm{BH}} \mathrm{V}
\end{gathered}
$$

According to what is indicated in Equation (15), it was supposed that there was no limitation of soluble organic substrate production by the hydrolysis step rate. Furthermore, it is noted that Equation (16) is similar to Equation (11).

Based on Equation (16), the concentration of the soluble organic substrate $\left(\mathrm{S}_{\mathrm{S}}\right)$ could be determined:

$$
\mathrm{S}_{\mathrm{S}}=\frac{\mathrm{K}_{\mathrm{S}}\left(1+\mathrm{b}_{\mathrm{H}} \mathrm{SRT}\right)}{\mu_{\mathrm{Hm}} \mathrm{SRT}-\left(1+\mathrm{b}_{\mathrm{H}} \mathrm{SRT}\right)}
$$

In addition, Equation (16) permitted the substitution of the switching function related to the soluble organic substrate $\left(\mathrm{S}_{\mathrm{S}}\right)$. Combining Equations (15) and (16), an expression of the heterotrophic biomass concentration in the bioreactor was obtained:

$$
\mathrm{X}_{\mathrm{BH}}=\frac{\mathrm{Y}_{\mathrm{H}}\left(\mathrm{S}_{\mathrm{S}_{\mathrm{i}}}+\mathrm{X}_{\mathrm{S}_{\mathrm{i}}}\right) \mathrm{SRT} / \mathrm{HRT}}{1+\mathrm{b}_{\mathrm{H}} \mathrm{SRT}\left(1-\mathrm{Y}_{\mathrm{H}}\left(1-\mathrm{f}_{\mathrm{P}}\right)\right)}
$$

Moving to autotrophic biomass activity, mass balance on ammonium was slightly different from what was indicated in Equation (3) as particulate organic products of the heterotrophic biomass were included:

$$
\mathrm{Q}\left(\mathrm{S}_{\mathrm{NH}_{\mathrm{i}}}+\mathrm{S}_{\mathrm{ND}_{\mathrm{i}}}+\mathrm{X}_{\mathrm{ND}_{\mathrm{i}}}\right)+\left(\mathrm{i}_{\mathrm{XB}}-\mathrm{f}_{\mathrm{p}} \mathrm{i}_{\mathrm{XP}}\right)\left(\mathrm{b}_{\mathrm{A}} \mathrm{X}_{\mathrm{BA}}+\mathrm{b}_{\mathrm{H}} \mathrm{X}_{\mathrm{BH}}\right) \mathrm{V}=\mu_{\mathrm{Am}}\left(\mathrm{i}_{\mathrm{XB}}+\frac{1}{\mathrm{Y}_{\mathrm{A}}}\right)\left(\frac{\mathrm{S}_{\mathrm{NH}}}{\mathrm{S}_{\mathrm{NH}}+\mathrm{K}_{\mathrm{NH}}}\right) \mathrm{X}_{\mathrm{BA}} \mathrm{V}
$$

For autotrophic bacteria, mass balance is given by Equation (20):

$$
\mu_{\mathrm{Am}} \frac{\mathrm{S}_{\mathrm{NH}}}{\mathrm{S}_{\mathrm{NH}}+\mathrm{K}_{\mathrm{NH}}} \mathrm{X}_{\mathrm{BA}} \mathrm{V}=\mathrm{Q}_{\mathrm{W}} \mathrm{X}_{\mathrm{BA}}+\mathrm{b}_{\mathrm{A}} \mathrm{X}_{\mathrm{BA}} \mathrm{V}
$$

From the latter, the same relation in Equation (5) was found. Equation (20) allows the calculation of ammonia concentration in the bioreactor:

$$
\mathrm{S}_{\mathrm{NH}}=\frac{\mathrm{K}_{\mathrm{NH}}\left(1+\mathrm{b}_{\mathrm{A}} \mathrm{SRT}\right)}{\mu_{\mathrm{Am}} \mathrm{SRT}-\left(1+\mathrm{b}_{\mathrm{A}} \mathrm{SRT}\right)}
$$


Autotrophic biomass concentration was determined by substituting the ammonium-switching function in Equation (19) using Equation (20):

$$
X_{B A}=Y_{A} \frac{\left(S_{N_{i}}+S_{N D_{i}}+X_{N_{i}}\right) S R T / H R T-X_{B H}\left(i_{X B}+f_{P} i_{X P} b_{H} S R T\right)}{1+i_{X B} Y_{A}+b_{A} S R T\left(1+Y_{A} f_{P} i_{X P}\right)}
$$

The term $\mathrm{X}_{\mathrm{BH}}\left(\mathrm{i}_{\mathrm{XB}}+\mathrm{f}_{\mathrm{p}} \mathrm{i}_{\mathrm{XP}} \mathrm{b}_{\mathrm{H}} \mathrm{SRT}\right)$ reveals the influence of heterotrophic lysis products on autotrophic biomass concentration.

Once biomass concentrations were determined, concentration expressions of the remaining state variables could be developed. Starting with nitrate and nitrite concentration $\left(\mathrm{S}_{\mathrm{NO}}\right)$, mass balance on these compounds is shown in Equation (23):

$$
\mathrm{r}_{\mathrm{S}_{\mathrm{NO}}} \mathrm{V}=\mathrm{QS}_{\mathrm{NO}}
$$

The production rate of nitrogen oxides ( $\mathrm{r}_{\mathrm{SNO}}$ ), corresponding to the ammonium oxidation rate, is dependent on the autotrophic biomass aerobic growth rate $\left(\mathrm{r}_{\mathrm{g}, \mathrm{XBA}}\right)$, as indicated in the ASM1 Petersen matrix:

$$
\mathrm{r}_{\mathrm{S}_{\mathrm{NO}}}=\frac{1}{\mathrm{Y}_{\mathrm{A}}} \mathrm{r}_{\mathrm{g}, \mathrm{X}_{\mathrm{BA}}}
$$

The concentration of nitrogen oxides in Equation (25) was obtained by a combination of Equations (23) and (24):

$$
\mathrm{S}_{\mathrm{NO}}=\frac{1+\mathrm{b}_{\mathrm{A}} \mathrm{SRT}}{\frac{\mathrm{SRT}}{\mathrm{HRT}} \mathrm{Y}_{\mathrm{A}}} \mathrm{X}_{\mathrm{BA}}
$$

As for lysis products present in the mixed liquor, particulate inert products are generated during biomass decay and extracted with sludge excess, as indicated in Equation (26):

$$
\mathrm{f}_{\mathrm{P}}\left(\mathrm{b}_{\mathrm{H}} \mathrm{X}_{\mathrm{BH}}+\mathrm{b}_{\mathrm{A}} \mathrm{X}_{\mathrm{BA}}\right) \mathrm{V}=\mathrm{Q}_{\mathrm{W}} \mathrm{X}_{\mathrm{P}}
$$

Consequently, the concentration of these products $\left(\mathrm{X}_{\mathrm{P}}\right)$ could be expressed as follows:

$$
X_{P}=f_{P}\left(b_{H} X_{B H}+b_{A} X_{B A}\right) S R T
$$

Since autotrophic lysis products were assumed to be negligible, it became

$$
\mathrm{X}_{\mathrm{P}}=\mathrm{f}_{\mathrm{P}} \mathrm{b}_{\mathrm{H}} \mathrm{X}_{\mathrm{BH}} \mathrm{SRT}
$$

Meanwhile, the concentration of particulate organic substrate $\left(X_{S}\right)$ is ruled by Equation (29):

$$
\left(1-f_{P}\right)\left(b_{H} X_{B H}+b_{A} X_{B A}\right) V=k_{h} \frac{X_{S} / X_{B H}}{X_{S} / X_{B H}+K_{X}} X_{B H} V+Q_{W} X_{S}
$$

where the first term is the production rate, and the second term is the hydrolysis rate. The last term, representing the amount extracted by means of waste sludge, is negligible compared to other terms, particularly for operations at high SRT. Consequently, $X_{S}$ expression is described by Equation (30):

$$
\mathrm{X}_{\mathrm{S}}=\frac{\mathrm{K}_{\mathrm{X}} \mathrm{X}_{\mathrm{BH}}}{\frac{\mathrm{k}_{\mathrm{h}} \mathrm{X}_{\mathrm{BH}}}{\left(1-\mathrm{f}_{\mathrm{P}}\right)\left(\mathrm{b}_{\mathrm{H}} \mathrm{X}_{\mathrm{BH}}+\mathrm{b}_{\mathrm{A}} \mathrm{X}_{\mathrm{BA}}\right)}-1}
$$

In the instance that autotrophic debris was omitted, the expression of $\mathrm{X}_{\mathrm{S}}$ became simpler:

$$
X_{S}=\frac{\left(1-f_{P}\right) b_{H}}{k_{h}-\left(1-f_{P}\right) b_{H}} K_{X} X_{B H}
$$


The concentration of inert particulates could easily be determined by Equation (32):

$$
X_{I}=\frac{S R T}{H R T} X_{I, i}=C_{F} X_{I, i}
$$

where $\mathrm{C}_{\mathrm{F}}$ is the concentration factor defined as the ratio of SRT by HRT.

In the same way as with inert particulates, it was possible to calculate the concentration of the inert colloidal compound $\left(\mathrm{S}_{\mathrm{Co}}\right.$; [12]). In fact, as $\mathrm{S}_{\mathrm{Co}_{0}}$ is slightly impacted by antifouling hydraulic turbulence, it thus builds up on the membrane, leading to a microscale fouling layer:

$$
\mathrm{S}_{\mathrm{Co}}=\frac{\mathrm{SRT}}{\mathrm{HRT}+\mathrm{SRT}\left(1-\mathrm{M}_{\mathrm{R}}\right)} \mathrm{S}_{\mathrm{Co}, \mathrm{i}}
$$

where $M_{R}$ is the membrane inert colloid retention rate.

\section{Results}

\subsection{Equation Validation and Testing}

Developed analytical expressions, summarized in Table 3, need to be validated using a data set.

Table 3. Analytical expressions of state variables of an aerated ASP/MBR assimilated to a continuously

\begin{tabular}{|c|c|}
\hline State Variable & Analytical Expression \\
\hline Heterotrophic biomass concentration (gCOD/L) & $\mathrm{X}_{\mathrm{BH}}=\frac{\mathrm{Y}_{\mathrm{H}}\left(\mathrm{S}_{\mathrm{S}_{\mathrm{i}}}+\mathrm{X}_{\mathrm{S}_{\mathrm{i}}}\right) \mathrm{SRT} / \mathrm{HRT}}{1+\mathrm{b}_{\mathrm{H}} \mathrm{SRT}\left(1-\mathrm{Y}_{\mathrm{H}}\left(1-\mathrm{f}_{\mathrm{P}}\right)\right)}$ \\
\hline $\begin{array}{l}\text { Concentration of Soluble organic } \\
\text { compounds }(\mathrm{gCOD} / \mathrm{L})\end{array}$ & $\mathrm{S}_{\mathrm{S}}=\frac{\mathrm{K}_{\mathrm{S}}\left(1+\mathrm{b}_{\mathrm{H}} \mathrm{SRT}\right)}{\mu_{\mathrm{Hm}} \mathrm{SRT}-\left(1+\mathrm{b}_{\mathrm{H}} \mathrm{SRT}\right)}$ \\
\hline $\begin{array}{l}\text { Concentration of particulate organic } \\
\text { compounds }(\mathrm{gCOD} / \mathrm{L})\end{array}$ & $\mathrm{X}_{\mathrm{S}}=\frac{\left(1-\mathrm{f}_{\mathrm{P}}\right) \mathrm{b}_{\mathrm{H}}}{\mathrm{k}_{\mathrm{h}}-\left(1-\mathrm{f}_{\mathrm{P}}\right) \mathrm{b}_{\mathrm{H}}} \mathrm{K}_{\mathrm{X}} \mathrm{X}_{\mathrm{BH}}$ \\
\hline Autotrophic biomass concentration (gCOD/L) & $X_{B A}=Y_{A} \frac{\left(S_{N_{i}}+S_{N_{i}}+X_{N_{i}}\right) S R T / H R T-X_{B H}\left(i_{X B}+f_{P} i_{X P} b_{H} S R T\right)}{1+i_{X B} Y_{A}+b_{A} S R T\left(1+Y_{A} f_{P} i_{X P}\right)}$ \\
\hline $\begin{array}{l}\text { Concentration of inert organic lysis } \\
\text { products }(\mathrm{gCOD} / \mathrm{L})\end{array}$ & $X_{P}=f_{P}\left(b_{H} X_{B H}+b_{A} X_{B A}\right) S R T$ \\
\hline Soluble ammonia concentration (gN/L) & $\mathrm{S}_{\mathrm{NH}}=\frac{\mathrm{K}_{\mathrm{NH}}\left(1+\mathrm{b}_{\mathrm{A}} \mathrm{SRT}\right)}{\mu_{\mathrm{Am}} \mathrm{SRT}-\left(1+\mathrm{b}_{\mathrm{A}} \mathrm{SRT}\right)}$ \\
\hline Nitrite and nitrate concentration (gN/L) & $\mathrm{S}_{\mathrm{NO}}=\frac{1+\mathrm{b}_{\mathrm{A}} \mathrm{SRT}}{\frac{\mathrm{SRT}}{\mathrm{HRT}} \mathrm{Y}_{\mathrm{A}}} \mathrm{X}_{\mathrm{BA}}$ \\
\hline Concentration of inert particulates $(\mathrm{g} / \mathrm{L})$ & $\mathrm{X}_{\mathrm{I}}=\frac{\mathrm{SRT}}{\mathrm{HRT}} \mathrm{X}_{\mathrm{I}, \mathrm{i}}$ \\
\hline Concentration of inert colloidal compounds (gCOD/L) & $\mathrm{S}_{\mathrm{Co}_{\mathrm{o}}}=\frac{\mathrm{SRT}}{\mathrm{HRT}+\mathrm{SRT}\left(1-\mathrm{M}_{\mathrm{R}}\right)} \mathrm{S}_{\mathrm{Co}_{\mathrm{i}} \mathrm{i}}$ \\
\hline
\end{tabular}
stirred tank reactor (CSTR).

For this purpose, simulations by the GPS-X software were conducted in order to generate realistic data, as explained in Section 2. A number of pseudoexperiments, with widely varying operation conditions, were considered, as stated in Table 1 . To be as realistic as possible, the COD/N ratio in the influent, corresponding to the total amount of organic substrates relative to the total amount of nitrogenous compounds present in the influent, must be among the usual range for domestic wastewater, with variable ratio values of less than 12 .

For all state variables and reaction rates, simulation results using previously developed analytical expressions were compared to results given by GPS-X simulations using full ASM1 when steady-state was reached. The latter could be identified when all state variables and reaction rates became constant over time. Steady-state is generally obtained after a function period that exceeds three times the SRT value. 
An acceptable match was obtained for all state variables, as shown in Figures 3-5. The SRT had a positive effect on particular compounds, which increased with rising SRT. The remaining soluble substrates $\left(\mathrm{S}_{\mathrm{S}}\right.$ and $\left.\mathrm{S}_{\mathrm{NH}}\right)$ decreased when SRT increased. This was not the case, however, for $\mathrm{S}_{\mathrm{NO}}$, which increased with SRT because the uptake of ammonia into the biomass decreased with high SRT. Unlike with SRT, increasing HRT had a negative influence on the sludge matrix composition: $X_{\mathrm{BH}}, \mathrm{X}_{\mathrm{BA}}$, $\mathrm{X}_{\mathrm{S}}, \mathrm{X}_{\mathrm{P}}$, and $\mathrm{X}_{\mathrm{I}}$ were diluted in the influent flow. If there was more substrate $\left(\mathrm{S}_{\mathrm{S}, \mathrm{i}}\right)$, there was a greater rise of particulate organic compound concentrations $\left(\mathrm{X}_{\mathrm{BH}}, \mathrm{X}_{\mathrm{S}}\right.$, and $\left.\mathrm{X}_{\mathrm{P}}\right)$. In fact, the concentration of $\mathrm{X}_{\mathrm{BH}}, \mathrm{X}_{\mathrm{S}}$, and $\mathrm{X}_{\mathrm{P}}$ are linear with $\mathrm{S}_{\mathrm{S}, \mathrm{i}}$.
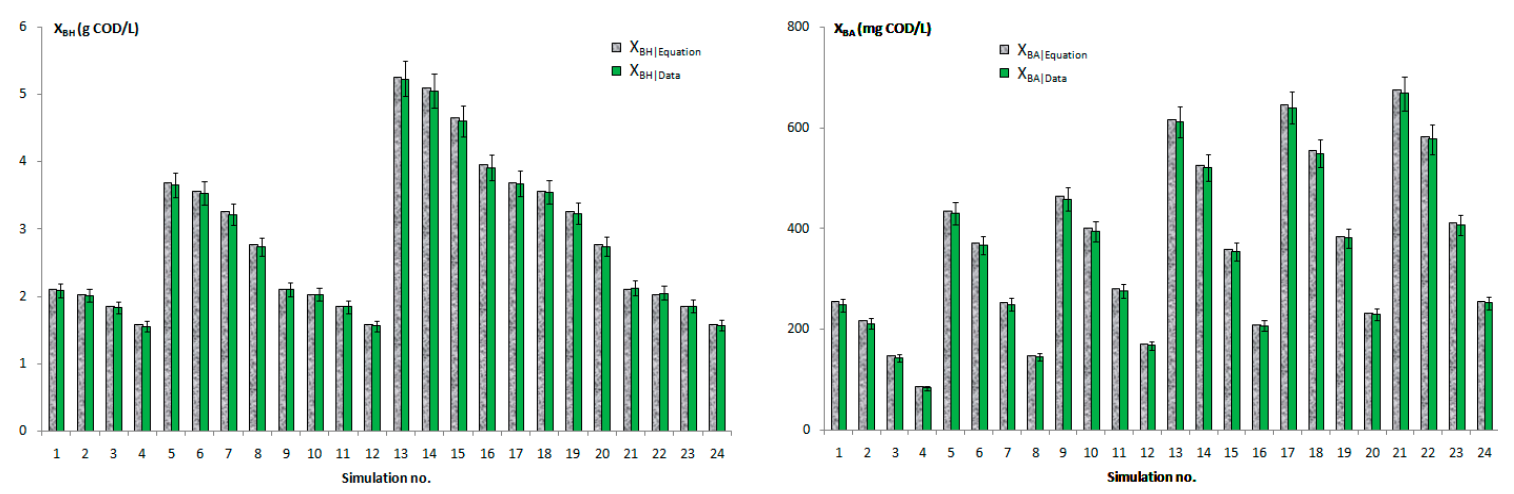

Figure 3. Active biomass concentration $\left(\mathrm{X}_{\mathrm{BH}}, \mathrm{X}_{\mathrm{BA}}\right)$ obtained by GPS- $\mathrm{X}$ software and Equations (18) and (22).

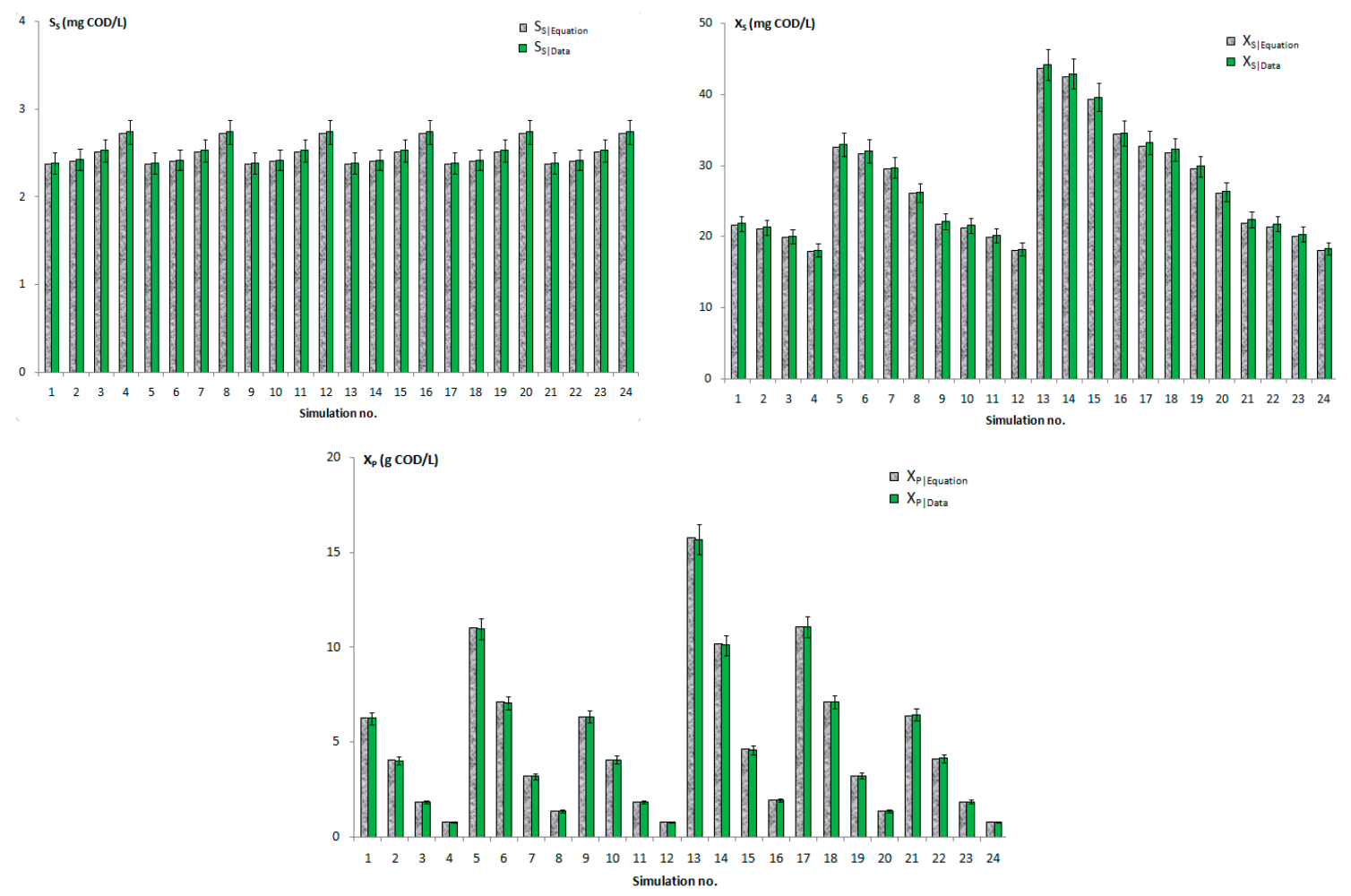

Figure 4. Concentrations of organic substrates $\left(\mathrm{S}_{\mathrm{S}}, \mathrm{X}_{\mathrm{S}}\right)$ and inert particulates $\left(\mathrm{X}_{\mathrm{P}}\right)$ obtained by GPS-X software and Equations (17), (28), and (31). 

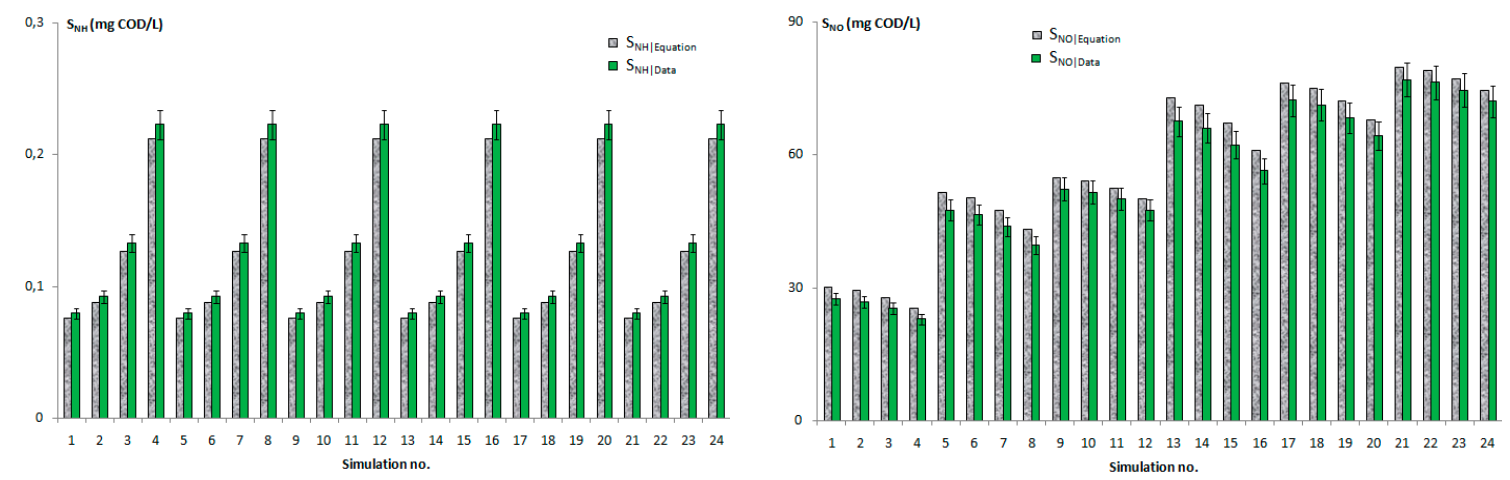

Figure 5. Nitrogen substrate concentration $\left(\mathrm{S}_{\mathrm{NH}}, \mathrm{S}_{\mathrm{NO}}\right)$ obtained by GPS-X software and Equations (20) and (23).

\subsection{Sensitivity Analysis}

Following this, a sensitivity analysis of four operating parameters- $\mathrm{S}_{\mathrm{S}, \mathrm{i}}, \mathrm{X}_{\mathrm{I}, \mathrm{i}}, \mathrm{SRT}$, and HRT-was performed with the aim of identifying if the developed steady-state expressions had the same sensitivity to these parameters as the full ASM1. For this reason, the normalized sensitivity coefficient, $\mathrm{S}_{\mathrm{ij}}$, giving the relative sensitivity of output $\mathrm{i}\left(\mathrm{y}_{\mathrm{i}}\right)$ respective to an operating parameter, $\mathrm{j}\left(\mathrm{x}_{\mathrm{j}}\right)$, was calculated according to Petersen et al. [13].

$$
S_{i j}=\left|\frac{x_{j}}{y_{i}} \frac{d y_{i}}{d x_{j}}\right|
$$

Depending on the $S_{i j}$ value, the parameter influence on the outputs could be classified, as shown in Table 4 . The derivatives $d y_{i}$ and $d x_{j}$ were determined numerically in a specific range if no analytical expressions were available [14]. Generally, $10 \%$ increase $(+10 \%)$ and $10 \%$ decrease $(-10 \%)$ of one parameter were applied to the calculation of $S_{\mathrm{ij}}$. In this study, the derivatives were calculated both numerically and analytically thanks to the developed steady-state equations. In the following, the steps of the analytical sensitivity analysis were detailed only for organic compounds in order to minimize the dimension of the tables. It should be mentioned that these analysis steps are still applicable for nitrogen treatment compounds $\left(\mathrm{X}_{\mathrm{BA}}, \mathrm{S}_{\mathrm{NH}}\right.$, and $\left.\mathrm{S}_{\mathrm{NO}}\right)$. Obtained expressions for different derivatives are gathered in Table 5. After that, expressions of sensitivity coefficients of state variables, depending on operating parameters, were also determined, as shown in Table 5. According to the steady-state equation, the sensitivity analysis can also be easily performed on stoichiometric and kinetic parameters [15].

The sensitivity analysis are calculated Table 6 and the results are summarized in Table 7. First of all, it can be noticed that the sensitivity analysis based on the steady-state expressions gave almost the same numerically calculated sensitivity coefficient values for all compounds. $\mathrm{S}_{\mathrm{S}, \mathrm{i}}$ and HRT did not have any influence on the soluble organic substrate concentration $S_{S}$.

Table 4. Classification of parameter influence according to $S_{\text {ii }}$ value.

\begin{tabular}{cc}
\hline $\mathrm{S}_{\mathrm{ij}}$ Value Range & Influence Classification \\
\hline $\mathrm{S}_{\mathrm{ij}} \geq 2$ & Extremely influential \\
$1 \leq \mathrm{S}_{\mathrm{ij}}<2$ & Very influential \\
$0.25 \leq \mathrm{S}_{\mathrm{ij}}<1$ & Influential \\
$\mathrm{S}_{\mathrm{ij}}<0.25$ & Not influential \\
\hline
\end{tabular}


Table 5. Analytical expressions of derivatives of organic compounds based on steady-state equations.

\begin{tabular}{|c|c|c|c|c|}
\hline $\mathrm{i}$ & SRT & HRT & $\mathrm{S}_{\mathrm{S}, \mathrm{i}}$ & $X_{I, i}$ \\
\hline $\mathrm{X}_{\mathrm{BH}}$ & $\begin{array}{c}\frac{\mathrm{d} \mathrm{X}_{\mathrm{BH}}}{\mathrm{dSRT}}= \\
\frac{\frac{\mathrm{Y}_{\mathrm{H}}}{\mathrm{HRT}}\left(\mathrm{S}_{\mathrm{S}, \mathrm{i}}+\mathrm{X}_{\mathrm{S}, \mathrm{i}}\right)}{\left[1+\mathrm{b}_{\mathrm{H}} \mathrm{SRT}\left(1-\mathrm{Y}_{\mathrm{H}}\left(1-\mathrm{f}_{\mathrm{P}}\right)\right)\right]^{2}}\end{array}$ & $\begin{array}{c}\frac{d X_{B H}}{d H R T}= \\
\frac{-Y_{H}\left(S_{S, i}+X_{S, i}\right) \frac{S R T}{H R T^{2}}}{1+b_{H} S R T\left(1-Y_{H}\left(1-f_{P}\right)\right)}\end{array}$ & $\begin{array}{c}\frac{\mathrm{d} \mathrm{X}_{\mathrm{BH}}}{\mathrm{dS}_{\mathrm{S}, \mathrm{i}}}= \\
\frac{\mathrm{Y}_{\mathrm{H}} \frac{\mathrm{SRT}}{\mathrm{HRT}}}{1+\mathrm{b}_{\mathrm{H}} \mathrm{SRT}\left(1-\mathrm{Y}_{\mathrm{H}}\left(1-\mathrm{f}_{\mathrm{P}}\right)\right)}\end{array}$ & $\frac{d X_{B H}}{d X_{I, i}}=0$ \\
\hline$x_{S}$ & $\begin{array}{c}\frac{d X_{S}}{d S R T}= \\
\frac{K_{X}\left(1-f_{P}\right) b_{H}}{\frac{k_{h}-\left(1-f_{P}\right) b_{H}}{H R T}\left(S_{S, i}+X_{S, i}\right)} \\
{\left[1+b_{H} S R T\left(1-Y_{H}\left(1-f_{P}\right)\right)\right]^{2}}\end{array}$ & $\begin{array}{c}\frac{d X_{S}}{d H R T}= \\
\frac{-K_{X}\left(1-f_{\mathrm{P}}\right) b_{H}}{k_{h}-\left(1-f_{\mathrm{P}}\right) b_{H}} Y_{H}\left(S_{S, i}+X_{S, i}\right) \frac{S R T}{H R T^{2}} \\
1+b_{H} S R T\left(1-Y_{H}\left(1-f_{P}\right)\right)\end{array}$ & $\begin{array}{c}\frac{d X_{S}}{d S_{S, i}}= \\
\frac{K_{X}\left(1-f_{\mathrm{P}}\right) b_{H}}{k_{h}-\left(1-f_{\mathrm{P}}\right) b_{H}} Y_{H} \frac{S R T}{H R T} \\
1+b_{H} S R T\left(1-Y_{H}\left(1-f_{P}\right)\right)\end{array}$ & $\frac{\mathrm{dX}_{\mathrm{S}}}{\mathrm{d} \mathrm{X}_{\mathrm{I}, \mathrm{i}}}=0$ \\
\hline $\mathrm{S}_{\mathrm{S}}$ & $\begin{array}{c}\frac{\mathrm{dS}_{\mathrm{S}}}{\mathrm{dSRT}}= \\
\frac{-\mu_{\mathrm{H}} \mathrm{K}_{\mathrm{S}}}{\left[\left(\mu_{\mathrm{H}}-\mathrm{b}_{\mathrm{H}}\right) \mathrm{SRT}-1\right]^{2}}\end{array}$ & $\frac{\mathrm{d} \mathrm{S}_{\mathrm{S}}}{\mathrm{dHRT}}=0$ & $\frac{d S_{\mathrm{S}}}{d S_{\mathrm{S}, \mathrm{i}}}=0$ & $\frac{\mathrm{d} \mathrm{S}_{\mathrm{S}}}{\mathrm{dX}}=0$ \\
\hline$X_{I}$ & $\frac{\mathrm{dX}_{\mathrm{I}}}{\mathrm{dSRT}}=\frac{1}{\mathrm{HRT}} \mathrm{X}_{\mathrm{I}, \mathrm{i}}$ & $\frac{\mathrm{dX}}{\mathrm{dHRT}}=-\frac{\mathrm{SRT}}{\mathrm{HRT}^{2}} \mathrm{X}_{\mathrm{I}, \mathrm{i}}$ & $\frac{d X_{I}}{\mathrm{dS}_{\mathrm{S}, \mathrm{i}}}=0$ & $\frac{\mathrm{dX}_{\mathrm{I}}}{\mathrm{dX} \mathrm{X}_{\mathrm{I}, \mathrm{i}}}=\frac{\mathrm{SRT}}{\mathrm{HRT}}$ \\
\hline
\end{tabular}

Table 6. Sensitivity coefficients calculated using developed steady-state equations.

\begin{tabular}{|c|c|c|c|c|}
\hline i & SRT & HRT & $\mathrm{S}_{\mathrm{S}, \mathrm{i}}$ & $X_{I, i}$ \\
\hline $\mathrm{X}_{\mathrm{BH}}$ & $\mathrm{S}_{\mathrm{X}_{\mathrm{BH}}, \mathrm{SRT}}=\frac{1}{1+\mathrm{b}_{\mathrm{H}} \mathrm{SRT}\left(1-\mathrm{Y}_{\mathrm{H}}\left(1-\mathrm{f}_{\mathrm{P}}\right)\right)}=\frac{1}{1+0.24 \mathrm{SRT}}$ & $\mathrm{S}_{\mathrm{X}_{\mathrm{BH}, \mathrm{HRT}}}=1$ & $\mathrm{~S}_{\mathrm{X}_{\mathrm{BH},} \mathrm{S}_{\mathrm{S}, \mathrm{i}}}=1$ & $\mathrm{~S}_{\mathrm{X}_{\mathrm{BH}}, \mathrm{X}_{\mathrm{I}, \mathrm{i}}}=0$ \\
\hline $\mathrm{X}_{\mathrm{S}}$ & $\mathrm{S}_{\mathrm{X}_{\mathrm{S}}, \mathrm{SRT}}=\frac{1}{1+\mathrm{b}_{\mathrm{H}} \mathrm{SRT}\left(1-\mathrm{Y}_{\mathrm{H}}\left(1-\mathrm{f}_{\mathrm{p}}\right)\right)}=\frac{1}{1+0.24 \mathrm{SRT}}$ & $\mathrm{S}_{\mathrm{X}_{\mathrm{S}}, \mathrm{HRT}}=1$ & $\mathrm{~S}_{\mathrm{X}_{\mathrm{S},} \mathrm{S}_{\mathrm{S}, \mathrm{i}}}=1$ & $\mathrm{~S}_{\mathrm{X}_{\mathrm{S}}, \mathrm{X}_{\mathrm{I}, \mathrm{i}}}=0$ \\
\hline $\mathrm{S}_{\mathrm{S}}$ & $\mathrm{S}_{\mathrm{S}_{\mathrm{S}}, \mathrm{SRT}}=\frac{-\mu_{\mathrm{H}} \mathrm{SRT}}{\left(1+\mathrm{b}_{\mathrm{H}} \mathrm{SRT}\right)\left[\mu_{\mathrm{H}} \mathrm{SRT}-\left(1+\mathrm{b}_{\mathrm{H}} \mathrm{SRT}\right)\right]}$ & $\mathrm{S}_{\mathrm{S}_{\mathrm{S}} \mathrm{HRT}}=0$ & $\mathrm{~S}_{\mathrm{S}_{\mathrm{S}} \mathrm{S}_{\mathrm{S}, \mathrm{i}}}=0$ & $\mathrm{~S}_{\mathrm{S}_{\mathrm{S}}, \mathrm{X}_{\mathrm{I}, \mathrm{i}}}=0$ \\
\hline$X_{P}$ & $\mathrm{~S}_{\mathrm{X}_{\mathrm{P}}, \mathrm{SRT}}=\frac{2+\mathrm{b}_{\mathrm{H}} \mathrm{SRT}\left(1-\mathrm{Y}_{\mathrm{H}}\left(1-\mathrm{f}_{\mathrm{P}}\right)\right)}{1+\mathrm{b}_{\mathrm{H}} \mathrm{SRT}\left(1-\mathrm{Y}_{\mathrm{H}}\left(1-\mathrm{f}_{\mathrm{P}}\right)\right)}=1+\frac{1}{1+0.24 \mathrm{SRT}}$ & $\mathrm{S}_{\mathrm{X}_{\mathrm{I}}, \mathrm{HRT}}=1$ & $\mathrm{~S}_{\mathrm{X}_{\mathrm{P}}, \mathrm{S}_{\mathrm{S}, \mathrm{i}}}=1$ & $\mathrm{~S}_{\mathrm{X}_{\mathrm{P}}, \mathrm{X}_{\mathrm{I}, \mathrm{i}}}=0$ \\
\hline$X_{I}$ & $\mathrm{~S}_{\mathrm{X}_{\mathrm{I}}, \mathrm{SRT}}=1$ & $\mathrm{~S}_{\mathrm{X}_{\mathrm{I}}, \mathrm{HRT}}=1$ & $\mathrm{~S}_{\mathrm{X}_{\mathrm{I}}, \mathrm{S}_{\mathrm{S}, \mathrm{i}}}=0$ & $S_{X_{I}, X_{I, i}}=1$ \\
\hline
\end{tabular}

Grey background show the non-connected variables.

Table 7. Sensitivity analysis of state variables from equation (Equ.) or software (GPS-X) according to operating parameter values.

\begin{tabular}{|c|c|c|c|c|c|c|c|c|c|c|c|c|}
\hline \multirow{3}{*}{$\begin{array}{c}\begin{array}{c}\text { Operating } \\
\text { Parameter j }\end{array} \\
\begin{array}{c}\text { Nominal } \\
\text { Value }\end{array} \\
\text { Output i }\end{array}$} & \multicolumn{6}{|c|}{ SRT (day) } & \multirow{2}{*}{\multicolumn{2}{|c|}{$\begin{array}{c}\text { HRT (h) } \\
8\end{array}$}} & \multirow{2}{*}{\multicolumn{2}{|c|}{$\begin{array}{c}\begin{array}{c}\mathrm{S}_{\mathrm{S}, \mathrm{i}} \\
(\mathrm{mgCOD} / \mathrm{L})\end{array} \\
600\end{array}$}} & \multirow{2}{*}{\multicolumn{2}{|c|}{$\frac{X_{\mathrm{I}, \mathrm{i}}(\mathrm{mg} / \mathrm{L})}{100}$}} \\
\hline & \multicolumn{2}{|c|}{10} & \multicolumn{2}{|c|}{30} & \multicolumn{2}{|c|}{50} & & & & & & \\
\hline & Equ. & GPS-X & Equ. & GPS-X & Equ. & GPS-X & Equ. & GPS-X & Equ. & GPS-X & Equ. & GPS-X \\
\hline $\mathrm{X}_{\mathrm{BH}}$ & 0.30 & 0.30 & 0.12 & 0.13 & 0.08 & 0.08 & 1.00 & 1.01 & 1.00 & 1.00 & 0.00 & 0.00 \\
\hline$X_{S}$ & 0.30 & 0.30 & 0.12 & 0.12 & 0.08 & 0.08 & 1.00 & 1.01 & 1.00 & 1.03 & 0.00 & 0.00 \\
\hline $\mathrm{S}_{\mathrm{S}}$ & 0.16 & 0.16 & 0.06 & 0.07 & 0.04 & 0.05 & 0.00 & 0.01 & 0.00 & 0.05 & 0.00 & 0.00 \\
\hline$X_{P}$ & 1.30 & 1.30 & 1.12 & 1.12 & 1.08 & 1.08 & 1.00 & 1.01 & 1.00 & 1.00 & 0.00 & 0.00 \\
\hline$X_{I}$ & 1.00 & 1.00 & 1.00 & 1.00 & 1.00 & 1.01 & 1.00 & 1.02 & 0.00 & 0.04 & 1.00 & 1.00 \\
\hline
\end{tabular}

Grey background are used when sensitivity analysis between the parameter is not influential.

It was found that SRT was very influential on $X_{P}$ concentration only and had a low influence on $S_{S}$. Concerning SRT influence on $S_{S}$, steady-state expressions gave less accurate $S_{i j}$ values, but, to some extent, these values are still reliable to quantify the low sludge-age influence on $\mathrm{S}_{\mathrm{S}}$. For the remaining organic state variables $\left(\mathrm{X}_{\mathrm{BH}}\right.$ and $\left.\mathrm{X}_{\mathrm{S}}\right)$, it was revealed that unlike with $\mathrm{S}_{\mathrm{S}, \mathrm{i}}$ and $\mathrm{HRT}$, the sensitivity of these concentrations to SRT strongly depended on the study value range: SRT was influential at lower values (around 10 days) and was not influential at higher values (higher than 30 days). This influence reduction was expected because of the Monod-type kinetics ruling the active biomass growth rate. However, the range-influence of SRT was clearly revealed in the analytical expression of the normalized sensitivity coefficients $\mathrm{S}_{\mathrm{XBH}, \mathrm{SRT}}$ and $\mathrm{S}_{\mathrm{XS}, \mathrm{SRT}}$, thanks to this approach.

Therefore, steady-state expressions of state variables showed high accuracy for concentration predictions and were able to successfully track the process state sensitivity to operating parameters. 
Consequently, the developed analytical expressions were validated; hence, they can be used for identification of optimum operating conditions. For this reason, rapid simulations were performed using the validated expressions, with the aim of investigating the impact of each operating parameter on system performance. Nominal values of operating parameters (SRT $=30$ day, HRT $=8 \mathrm{~h}$, $\mathrm{S}_{\mathrm{S}, \mathrm{i}}=600 \mathrm{mgCOD} / \mathrm{L}, \mathrm{X}_{\mathrm{I}, \mathrm{i}}=100 \mathrm{mg} / \mathrm{L}$ ) were considered for these simulations.

\section{Discussion}

Analyzing the sensitivity of operating, stoichiometric, and kinetic parameters can be challenging and time-consuming. The steady-state equation provides a better understanding of the meaning of the different process variables and main parameters. It also allows the simplest method of plotting the current interactions between the process and the stoichiometric and kinetic parameters. Due to the complexity of the biological processes and membrane filtration phenomena taking place in MBR-based systems, the steady-state equation presents the optimal way to operate an MBR-based system by providing the composition of the suspended solids impacting the macroscale fouling as the value of colloidal and soluble fractions that feed the microscale fouling layer [16].

It is noteworthy to mention that the analytical expressions developed in this study have a wide applicability range, thanks to the low number of assumptions. This makes it possible to fix the initial condition before starting simulation or to explain the impact of an operating parameter on effluent quality (EQ) or on mixed-liquor suspended solids composition. Moreover, the steady-state equation allows the identification of the most sensitive parameters and provides pointers for initiating the elaboration of procedures for model parameter determination. It could also allow WWTP managers to understand which operating variables/parameters should be assessed for solving a determined problem $[17,18]$. Subsequently, state variables and sensitivity coefficients of organic compounds of an aerated ASP assimilated to a CSTR, with complete retention of particulate compounds, or an aerated MBR assimilated to a CSTR have the analytical expressions summarized in Tables 3 and 6 .

\section{Conclusions}

An approach based on steady-state ASM1 mass balances is presented for ASM1 simplification. The advantage of the adopted approach is that it uses relatively few assumptions to ensure an accurate model. After development, nine analytical expressions were obtained, describing the concentrations of the main state variables present in the sludge matrix: $\mathrm{X}_{\mathrm{BH}}, \mathrm{X}_{\mathrm{S}}, \mathrm{S}_{\mathrm{S}}, \mathrm{X}_{\mathrm{BA}}, \mathrm{S}_{\mathrm{NH}}, \mathrm{S}_{\mathrm{NO}}, \mathrm{X}_{\mathrm{P}}, \mathrm{X}_{\mathrm{I}}$, and $\mathrm{S}_{\mathrm{Co}}$. Validation was then performed by means of data generation, using software simulations of the full ASM1. The steady-state expressions showed satisfying predictions of the state variable concentrations and were able to give a quite-accurate sensitivity analysis of state variables to the operating parameters. Therefore, these relatively simple expressions may be useful to understand the impact of operating parameters, which is of great importance in this field, providing researchers and practitioners with a standardized set of state variable values. Moreover, the sensitivity analysis based on these equations shows the complex interaction between all parameters. It provides a significantly better understanding of activated sludge and MBR applications, such as optimization, control, or design.

In addition, the obtained analytical expressions of this study are still applicable for the design and control of each ASP process that can be assimilated to a CSTR in the steady-state conditions, which is a very common configuration in WWTP. If a different process configuration is set, mass balance equations should be slightly modified to include the configuration impact, and then new analytical expressions for state variables and sensitivity coefficients suited for the new configuration can be generated.

Author Contributions: Conceptualization, A.L. and G.L.; writing-review and editing, M.H.; project administration, A.H. All authors have read and agreed to the published version of the manuscript.

Funding: This research was funded by the Averroes Tunisia/France exchange program and the French Water Agency.

Conflicts of Interest: The authors declare no conflict of interest. 


\section{References}

1. Naessens, W.; Maere, T.; Nopens, I. Critical review of membrane bioreactor models—Part 1: Biokinetic and filtration models. Biores. Technol. 2012, 122, 95-106. [CrossRef] [PubMed]

2. Hreiz, R.; Latifi, M.A.; Roche, N. Optimal design and operation of activated sludge processes: State-of-the-art. Chem. Eng. J. 2015, 281, 900-920. [CrossRef]

3. Hauduc, H.; Gillot, S.; Rieger, L.; Ohtsuki, T.; Shaw, A.; Takács, I.; Winkler, S. Activated sludge modelling in practice: An international survey. Water Sci. Technol. 2009, 60, 1943-1951. [CrossRef] [PubMed]

4. Henze, M.; Gujer, W.; Mino, T.; Van Loosedrecht, M. Activated Sludge Models ASM1, ASM2, ASM2d and ASM3. Water Intell. Online 2015, 5. [CrossRef]

5. Queinnec, I.; Gómez-Quintero, C.-S. Reduced modeling and state observation of an activated sludge process. Biotechnol. Prog. 2009, 25, 654-666. [CrossRef] [PubMed]

6. Cadet, C. Simplifications of Activated Sludge Model with preservation of its dynamic accuracy. IFAC Proc. Vol. 2014, 47, 7134-7139. [CrossRef]

7. Cruz, J.A.S.; Mussati, S.; Scenna, N.J.; Gernaey, K.V.; Mussati, M.C. Reaction invariant-based reduction of the activated sludge model ASM1 for batch applications. J. Environ. Chem. Eng. 2016, 4, 3654-3664. [CrossRef]

8. Anderson, J.S.; Kim, H.; Mc Avoy, J.T.; Hao, O.J. Control of an alternating aerobic-anoxic activated sludge system-Part 1: Development of a linearization-based modeling approach. Contr. Eng. Pract. 2000, 8, 271-278. [CrossRef]

9. Benhalla, A.; Houssou, M.; Charif, M. Linearization of the full activated sludge model No 1 for interaction analysis. Bioprocess Biosyst. Eng. 2010, 33, 759-771. [CrossRef] [PubMed]

10. Smets, I.Y.; Haegebaert, J.V.; Carrette, R.; Van Impe, J. Linearization of the activated sludge model ASM1 for fast and reliable predictions. Water Res. 2003, 37, 1831-1851. [CrossRef]

11. Fenu, A.; Guglielmi, G.; Jimenez, J.; Spèrandio, M.; Saroj, D.; Lesjean, B.; Brepols, C.; Thoeye, C.; Nopens, I. Activated sludge model (ASM) based modelling of membrane bioreactor (MBR) processes: A critical review with special regard to MBR specificities. Water Res. 2010, 44, 4272-4294. [CrossRef] [PubMed]

12. Brepols, C.; Comas, J.; Harmand, J.; Heran, M.; Robles, Á.; Rodriguez-Roda, I.; Ruano, M.V.; Smets, I.; Mannina, G. Position paper-Progress towards standards in integrated (aerobic) MBR modelling. Water Sci. Technol. 2020, 81, 1-9. [CrossRef] [PubMed]

13. Petersen, B.; Gernaey, K.; Henze, M.; Vanrolleghem, P.A. Calibration of Activated Sludge Models: A Critical Review of Experimental Designs; Springer: Berlin, Germany, 2003; pp. 101-186.

14. Diehl, S.; Zambrano, J.; Carlsson, B. Steady-state analysis of activated sludge processes with a settler model including sludge compression. Water Res. 2016, 88, 104-116. [CrossRef] [PubMed]

15. Cosenza, A.; Mannina, G.; Vanrolleghem, P.A.; Neumann, M.B. Variance-based sensitivity analysis for wastewater treatment plant modelling. Sci. Total. Environ. 2014, 470, 1068-1077. [CrossRef] [PubMed]

16. Heran, M.; Aryal, R.; Shon, H.K.; Vigneswaran, S.; Elmaleh, S.; Grasmick, A. Determining Criteria to optimize HF SMBR control. Water Environ. Res. 2012, 84, 115-119. [CrossRef] [PubMed]

17. Mannina, G.; Ni, B.-J.; Rebouças, T.F.; Cosenza, A.; Olsson, G. Minimizing membrane bioreactor environmental footprint by multiple objective optimization. Biores. Technol. 2020, 302, 122824. [CrossRef] [PubMed]

18. Demir, S.; Demir, N.M. Implementation of Activated Sludge Model No. 3 as an educational tool: BioXL3. Comput. Appl. Eng. Educ. 2020, 28, 1154-1173. [CrossRef]

Publisher's Note: MDPI stays neutral with regard to jurisdictional claims in published maps and institutional affiliations.

(C) 2020 by the authors. Licensee MDPI, Basel, Switzerland. This article is an open access article distributed under the terms and conditions of the Creative Commons Attribution (CC BY) license (http://creativecommons.org/licenses/by/4.0/). 